\title{
The Genre Debate: 100 Years of the Succession Narrative
}

An examination of the irony in the $\mathrm{SN}$ revealed numerous important instances of verbal irony and, thus demonstrates a pervasive sense of irony. Verbal irony is the main type of irony used in satirical attacks. I conclude, therefore, that the SN is a satire. I note that this is consistent with the SN being a historically based narrative and with it having a primarily theological purpose. For although satire is a form of literary art it can, nevertheless, be based on actual events. Moreover, satire frequently serves a larger purpose, be that purpose political or, in the case of the SN, theological. This overall finding that the $\mathrm{SN}$ is a satire leads us into the genre debate. Therefore, in order to make a stronger argument for the $\mathrm{SN}$ as a work of satire, in this chapter I provide a comparative discussion of the various competing genres: satire; national epic; propaganda; wisdom literature; theological history; and literary art. I begin by providing an account of satire.

\subsection{Satire}

\subsubsection{Identifying Satire}

As already mentioned, the findings of this research demonstrate that the $\mathrm{SN}$ is a work of satire. As already discussed (1.2.1.2.), satire does not adhere to a strict form. For satire can take the form of an essay, a theatre production, a cartoon or, an entire narrative. However, in the case of a narrative, satire can be identified by its content. Moreover, satire has a clear object of attack. ${ }^{1}$ This work has demonstrated that David is a clear object of attack and, indeed, the primary object of attack. It has also demonstrated that Absalom, Amnon, Solomon and some other members of the royal court are clear objects of attack. Furthermore, the object of satirical attack is usually a political or religious figure. ${ }^{2}$ In this case, David is the King of Israel, which is both a political and a religious position. Moreover, the object of satirical attack is usually a real person, ${ }^{3}$ as David was.

1 Highet, The Anatomy of Satire, 14.

2 Hodgart, Satire, 189.

3 Highet, The Anatomy of Satire, 14. 
This work has demonstrated that the $\mathrm{SN}$ has a pervasive sense of irony and, indeed, of verbal irony. The application of Muecke's taxonomy of verbal irony to the SN revealed numerous important examples of verbal irony. This finding in itself is probably sufficient to demonstrate that the $\mathrm{SN}$ is a work of satire. However, to demonstrate with certainty that the $\mathrm{SN}$ is a satire I have provided instances of the other features of satire including fantastic events; ${ }^{4}$ grotesqueries; ${ }^{5}$ distortions; ${ }^{6}$ ridicule $;{ }^{7}$ parody; ${ }^{8}$ and/or rhetorical features. ${ }^{9}$

\subsubsection{Findings as They Relate to the Work of Other Scholars}

10.1.2.1 Early History of Interpretation

In this section I compare and contrast my findings, with reference to genre and the overall purpose of the $\mathrm{SN}$, with the findings of scholars who contributed to the early study of the genre of this narrative, including, Wellhausen, ${ }^{10}$ Luther, ${ }^{11}$ Caspari, ${ }^{12}$ Gressmann, ${ }^{13}$ Schulz, ${ }^{14}$ and Rost. ${ }^{15}$

My findings oppose Wellhausen's suggestion that the narrative from 2 Samuel 9-20-1 Kings 2 is simply history writing. ${ }^{16}$ The irony in 2 Samuel 9-201 Kings 2 is too pronounced to support the claim that the documentation of history is the primary focus of the narrative. For the portrayal of David and the events in the $\mathrm{SN}$ is highly stylised and focused on the pejorative criticism of David rather than portraying a detailed and entirely accurate historical account of events. Moreover, Wellhasuen's claim that the narrative is pro-David ${ }^{17}$ cannot be sustained, given my findings.

Luther's suggestion that the narrative in Second Samuel and First Kings is an example of novelistic writing ${ }^{18}$ has some commonality with the findings of this research. Certainly, there is evidence that the narrative has been crafted to create a story with suspense, psychological tension, and a conflict around the

See 9.1.1.
See 9.1.2.
See 9.1.3.
See 9.1.4.
See 9.1.5.
See 9.1.6.
o Wellhausen, Prolegomena to the History of Ancient Israel.
1 Luther, "The Novella of Judah and Tamar and Other Israelite Novellas."
2 Caspari, "The Literary Type and Historical Value of 2 Samuel 15-20."
3 Gressmann, "The Oldest History Writing in Israel."
4 Schulz, "Narrative Art in the Books of Samuel."
5 Rost, The Succession to the Throne of David.
6 Wellhausen, Prolegomena to the History of Ancient Israel, 262.
7 Ibid., 294.
8 Luther, "The Novella of Judah and Tamar and Other Israelite Novellas," 13.


central character. These features are features of satire and the novel. However, unlike novelistic writing, the primary purpose of a satire is not to create an entertaining story but rather to offer a critique of some aspect of society or, at least, of the protagonist of the story. My findings demonstrate that the SN is intended to heavily criticize David, Absalom, Amnon, Solomon and certain other members of the royal court in Israel. Contrary to what Luther claims, the SN is not complimentary to David. Luther claims that the juxtaposition of David's despotism and his faith ${ }^{19}$ show the complexities of David's character as though this narrative is a biography of David. On the contrary, I suggest that the portrayal of David as a despot is quite simply done because the author believed that David was in fact a despot. Moreover, David is not shown to be particularly faithful. He does not adhere to the laws, he does not accept God's punishment without reservation (2 Sam. 12:22), he creates spy systems rather than trusting in God's favour (2 Sam. 15:24-29), and in the story of Shimei, although David mentions that Shimei's cursing is an act of God (2 Sam. 16:10), he later has Shimei murdered for this same act of cursing (1 Kgs. 2:8-9). Moreover, God is critical of David's behaviour (2 Sam. 11:27, 12:7-13). Luther's argument that this narrative has been crafted to highlight David's faith is therefore unsound. Nevertheless, Luther is arguably correct in claiming that ultimately God can be trusted because God punishes David.

My findings are congruent with Caspari's claim that the narrative is not history writing for the reasons that (a) the author was not objective in the material that he/she chose to include in the drama, and (b) the material is presented in a dramatized manner. ${ }^{20}$ Caspari suggests that although the narrative in Second Samuel and First Kings has elements in common with the novella, it is more likely to be historiography. ${ }^{21}$ The purpose of a satire is similar to that of a novella. Both genres reflect on past or present injustices in order to aid the progressive evolution of thought, and of institutions. However, satire is the more serious genre. Caspari suggests that this narrative is too serious to be a novella and, therefore, it should be regarded as historiography. ${ }^{22}$ My findings support the conclusion that the $\mathrm{SN}$ is a more serious piece of writing than a novella. Nevertheless, it does not follow that it is historiography. Indeed, as has already been made clear, there are simply too many literary flourishes and, in particular, too much irony, for the claim that the SN is historiography to be persuasive. Rather the claim that the genre of the $\mathrm{SN}$ is satire is far more compelling.

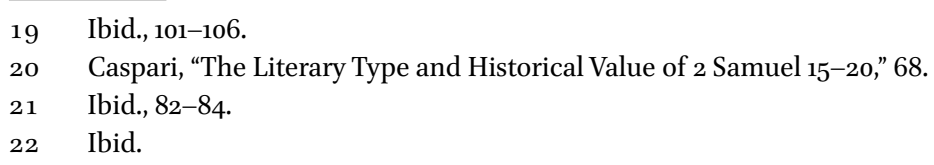


Gressmann's view on the genre of the SN (or, at least, the narrative which will later be called the $\mathrm{SN}$ ) is not dissimilar to the views of Luther and Caspari. Gressmann's only departure from Luther and Caspari is his claim that there are elements of the narrative which conform to the genre of saga. An example of this is the story of Uriah carrying his own death note. ${ }^{23}$ Although in the SN there is the presence of themes which are consistent with sagas, my findings undermine the proposition that the $\mathrm{SN}$ as a whole is a saga. For sagas are not normally heavily ironic.

Schulz argues that the material in Second Samuel and First Kings is mainly prose. ${ }^{24}$ As previously noted, this suggestion is not inconsistent with a finding in favour of satire. Satire can exist within a work of prose, notwithstanding the presence of the satirical elements of verbal irony etc. Moreover, some of Schulz's claims about the artistic representations in the story apply to the genre of satire. For instance, repetitions, "heightening," "heightening and retardation" "comic relief," and "vividness,"25 are consistent with satirical writing. However, Schulz's argument that the narrator was reluctant to pass judgement on David, for example, is not consistent with the notion of the SN as a work of satire. It is true that the author's judgement in a satire can be masked by the use of irony. For the ironist dissimulates and does not explicitly convey judgement, except in cases of overt irony. However, in a satire it is likely that there is explicit condemnation of the protagonist of the narrative at some point. In the SN David is explicitly criticized on a number of occasions, most notable by God (2 Sam. 12:7-14).

\subsubsection{National Epic}

I strongly oppose the classification of the $\mathrm{SN}$ as a national epic. The pejorative criticism of David, Absalom etc. inherent in the SN negates the view that this narrative was written in order to document the great achievements of the monarchy. Specifically, the SN is not a heroic portrayal of David. Pfeiffer confuses the historically known achievements of King David with the portrayal of David in the SN. Certainly, there is an argument that David was a successful statesman who united Israel and secured Israel's borders. However, regardless of these impressive feats, the author of the narrative is extremely critical of David as I have shown. Pfeiffer's claim that the author of the SN is usually objective and only biased in so much as he displays national pride, ${ }^{26}$ is not

\footnotetext{
23 Gressmann, "The Oldest History Writing in Israel," 17-28.

24 Schulz, "Narrative Art in the Books of Samuel," 120-121.

25 Ibid., 147-158.

26 Pfeiffer, Introduction to the Old Testament, 357-358.
} 
persuasive. It would seem highly unlikely that the author of the SN was primarily motivated, or even strongly influenced, by national pride.

10.1.2.3 Propaganda

Thornton, ${ }^{27}$ Hoffman, ${ }^{28}$ McCarter, ${ }^{29}$ and Whitelam ${ }^{30}$ argue that the genre of the $\mathrm{SN}$ is propaganda. That the $\mathrm{SN}$ belongs to the genre of propaganda is in some ways supported by the findings of this research; specifically, it is supported if the propaganda is considered to be anti-David, Absalom, Amnon and Solomon. On the other hand, the proposition that the SN is pro-David propaganda is obviously false. As we have seen, this research demonstrates that the SN is highly critical of David, his sons Absalom Amnon and Solomon, and various other members of the royal court. Yet, even if the propaganda in question were to be considered to be anti-David, the view that the $\mathrm{SN}$ is propaganda is somewhat implausible. There are striking differences between propaganda and satire. Propaganda is largely explicit, and the criticism in satire largely covert or implicit. Since the criticism in the SN is in large part irony-based implicit criticism, the $\mathrm{SN}$ is more plausibly regarded as satire than propaganda.

Thornton's idea that the SN was written in order to show that Solomon was the rightful heir to the throne ${ }^{31}$ warrants further discussion. Certainly, Solomon is spoken of as God's favoured son of David (2 Sam. 12:24). However, later in the narrative Adonijah is presented as the rightful heir to the throne and Solomon as an illegitimate king. Regardless of this, as stated, if the SN was propaganda, it would be more explicit and less ambiguous, and more inclined to direct statements than to dissimulation. ${ }^{32}$ Thereby, satire is a stronger candidate for the genre of the $\mathrm{SN}$, since satire while critical is also in large part, indirect.

Similarly, Hoffner takes the approach that this writing is a court apology which was written in order to legitimise Solomon's rise to the throne. ${ }^{33}$ However, in order to accept this proposition, it is necessary to ignore the suspicious deaths of Adonijah, Joab and possibly Shimei. It is also worth noting Gunn's remark that Solomon is rarely spoken of in the SN. Therefore, it is plausible that the focus of the SN was David. ${ }^{34}$ I argue that the salient function of the SN is to critique David in order to highlight the deficiencies of David's

\footnotetext{
27 Thornton, "Solomonic apologetic in Samuel and Kings."

28 Hoffner, "Propaganda and Political Justification in Hittite Historiography."

29 McCarter Jr., "Plots, True or False:" The Succession Narrative as Court Apology."

3o Whitelam, "The Defence of David."

31 Thornton, "Solomonic apologetic in Samuel and Kings," 160-161.

32 Gillian Keys, Wages of Sin, 22.

33 Hoffner, "Propaganda and Political Justification in Hittite Historiography," 49-62.

34 Gunn, The Story of David, 82.
} 
reign in and of themselves. To a lesser degree, the SN criticizes the reign of King Solomon.

McCarter's argument that the SN is propaganda serving to show Solomon as a decisive king and David as a gentle king is unlikely. ${ }^{35}$ In order to make this latter suggestion plausible McCarter would have to ignore David's treatment of Uriah (2 Sam. 11:14) among others. Similarly, Whitelam's suggestion that the $\mathrm{SN}$ is a piece of royal propaganda which is designed to present the stability of David's kingdom ${ }^{36}$ is questionable, given that David fled from Jerusalem $(2$ Sam. 15-16) and almost lost the kingdom to Absalom (2 Sam. 15-18). Moreover, arguably the SN is not pro-David propaganda since it does not give the impression that David was the innocent victim of Absalom's unstable behaviour, but rather that David was the cause of it.

\subsubsection{Wisdom Literature}

Whybray's suggestion that the SN was written as a teaching guide for students who were due to work in the royal court is intriguing. ${ }^{37}$ There are certainly examples in this narrative which present as pedagogic. However, if this were to be the case, it would be expected that there would be clear and unambiguous outcomes in the narrative. More often the outcomes are unresolved. For instance, the story of Amnon and Tamar does not resolve the question as to the correct punishment for the rape of a sibling. Therefore, it is unlikely that $\mathrm{SN}$ could function as a guide to students in respect of the law. Moreover, the illustrations of wisdom are few and far between. For example, the putatively wise characters of Jonadab and the 'wise' woman of Tekoa do not prove to be wise at all but rather crafty and manipulative. Indeed, Ridout's claim that the instances of apparent wisdom in this narrative are actually ironic ${ }^{38}$ is consistent with my findings.

Moreover, James Crenshaw argues that Whybray's conclusion is too broad. Crenshaw suggests that Whybray fails to identify style and ideas which are fundamentally of the wisdom tradition. Crenshaw argues that the theme of retribution is a staple of legal material, the motif of a controlling God is prominent in most biblical traditions, and the attitude to the cult in Proverbs is not dissimilar to the attitude to the cult in the prophetic tradition. Moreover, he remarks that ethical conduct, humility, and private prayer were as much a focus for the prophets and the priests as they were for the wisdom tradition.

\footnotetext{
35 McCarter Jr., "Plots, True or False." The Succession Narrative as Court Apology," $362-363$.

36 Whitelam, "The Defence of David," 62.

37 Whybray, The Succession Narrative. A Study of II Sam. 9-20 and I Kings 1 and 2, 56.

38 Ridout, "Prose Composition Techniques in the Succession Narrative (2 Sam 7, 9-20; 1 Kings 1-2)," 125-139.
} 
Crenshaw also points out that Whybray does not adequately explain why there are elements in the SN that are not familiar to the wisdom tradition, and why 'wisdom' is sometimes portrayed as manipulative. ${ }^{39}$

\subsubsection{Theological 'History' Writing}

Von Rad, ${ }^{40}$ Brueggemann ${ }^{41}$ McKenzie, ${ }^{42}$ and Mann ${ }^{43}$ argue for the $\mathrm{SN}$ as belonging to a genre that is best described as theological 'hisotry' writing. For Von Rad, the SN was more than a story that documented the succession to the throne of David. He suggests that in addition to telling the story of the Davidic dynasty, the SN explicated how the new institution of the dynastic monarchy would operate. Thus, Von Rad highlights the historical nature of the writing. ${ }^{44}$ In theological terms, Von Rad suggests that the $\mathrm{SN}$ is a history that not only speaks of the lives of the leaders, but embraces every aspect of life, both sacred and profane. ${ }^{45}$ I argue that Von Rad's claim that the main purpose of the SN was to document history ${ }^{46}$ is somewhat implausible, given the extent of the irony in the narrative.

Walter Brueggemann also suggests that the genre of the SN is historical/ theological writing. In particular he maintains that the theme of succession in 2 Samuel 9-20; 1 Kings $1-2$ is theologically significant as it emphasises the working out of Yahweh's promise to David, and Israel. ${ }^{47}$ The message of the narrative is then God's gift of life in the face of human freedom. ${ }^{48}$ This freedom is distinct from a bond to religious conventions which Brueggemann suggests is contrasted with a charismatic experience of faith. ${ }^{49}$ Thus, David's faith in God despite his humanness is the focus of this narrative. ${ }^{50}$

39 J. L. Crenshaw, "Method in Determining Wisdom Influence upon 'Historical' Literature," JBL 88, no. 2 (1969), 129-142. 138-140.

40 Von Rad, "The Beginnings of Historical Writing in Ancient Israel."

41 Brueggemann, "On Trust and Freedom: A Study of Faith in the Succession Narrative," and David's Truth in Israel's Imagination and Memory.

42 McKenzie, King David. A Biography.

43 Mann, Run, David, Run! An Investigation of the Theological Speech Acts of David's Departure and Return (2 Samuel 14-20).

44 Von Rad writes that historical writing is a product of the political changes of the day, as it is these changes which constitute what we understand as 'history.' Ibid., 145 .

45 Ibid., 153.

46 Von Rad, "The Beginnings of Historical Writing in Ancient Israel," 145.

47 Walter Brueggemann, "On Trust and Freedom: A Study of Faith in the Succession Narrative," Int, 26 (1972), 3-19, 4.

48 Ibid., 6.

49 Ibid., 7-8.

5o Ibid., 8. See also, Walter Brueggemann, David's Truth in Israel's Imagination and Memory (Minneapolis: Fortress Press, 1985), 41-66. 
Brueggemann's claim that the SN displays a charismatic understanding of God and is not concerned with traditions ${ }^{51}$ is also somewhat implausible, given the emphasis in the SN on the transgressions of David and others, and the disastrous consequences of these transgressions, notably David's punishment. David's alleged profound faith in God is also implausible, given that the occasions in the narrative which refer to David's faith present it as at best ambivalent, if not insincere (2 Sam. 12:18-21; 15:25; 33-37) and, indeed, ridicule David rather than praise him for this faith.

Steven Mann, who accepts Brueggemann's idea of David as a model of faith, suggests that the theme of sin and punishment is subordinate to the themes of David's faith in Yahweh, and David's hope for God's mercy. ${ }^{52}$ Mann argues that the theme that Yahweh protects all Israelites and brings exiles home encourages, a "hermeneutic of self-involvement" from the audience.

Mann's claim that the theme of sin and punishment is subordinate to David's model faith in Yahweh ${ }^{53}$ is diametrically opposed to my findings. Mann's claim is not plausible given that David's faith is evidently weak, used by David to manipulate others and/or misguided (2 Sam. 12:18-21; 15:25; 33-37). Moreover, the severe punishment of David's sins (2 Sam. 12:7-14), and the playing out of this punishment in terms of the death of Absalom etc., do not point to David's faith but instead to the problem of David's transgressions. Mann's theory that the SN, when considered as a theological tool encourages a "hermeneutic of self-involvement," ${ }^{24}$ is problematic as it is contingent upon the reader caring for David, and David caring for Yahweh. This is highly contestable given that David does not follow the laws, nor is David shown to be grateful to God (2 Sam. 12:8-9). Similarly, Mann's claim that this narrative is a narrative of hope is not persuasive in the sense that David is a model of faith. It may, however, be argued that the $\mathrm{SN}$ is a narrative of hope in so far as it points to the need for political, social, and theological reform. Such is the purpose of satire.

McKenzie's claim is that the SN is part of the Deuteronomistic History. McKenzie suggests that the latter is a theological history which sought to show the dangers of disobeying the laws, and which became instructive for later generations. ${ }^{55}$ This view is highly plausible as far as it goes. Certainly, the SN portrays the dangers for the moral order of breaking the law, especially

\footnotetext{
$51 \quad$ Brueggemann, "On Trust and Freedom: A Study of Faith in the Succession Narrative," 7-8.

52 Steven T. Mann, Run, David, Run! An Investigation of the Theological Speech Acts of David's Departure and Return (2 Samuel 14-20) (Indiana: Eisenbrauns Inc., 2013), 7 .

53 Mann, Run, David, Run! An Investigation of the Theological Speech Acts of David's Departure and Return (2 Samuel 14-20), 7.

54 Ibid., 158.

55 McKenzie, King David. A Biography, 27.
} 
by kings and other leaders. However, McKenzie has not focused on the ironic dimension of the SN, let alone characterised the SN as satire. However, my findings, namely, that the SN is a satire, are consistent with McKenzie's view of the SN as theological history. For the events depicted in the SN are historically based. Moreover, satire serves a purpose, and in the case of the SN, this purpose is theological.

\subsubsection{Literary Art}

My argument builds on the trajectory of thought that the SN is a work of literary art. The schoalrs of primary interest here are Eissfeldt, ${ }^{56}$ and Gunn. ${ }^{57}$ Otto Eissfeldt suggests that the $\mathrm{SN}$ outlines historical events, but does so in a way that is artistically crafted. ${ }^{58} \mathrm{He}$ proposes that the $\mathrm{SN}$ cannot be called history writing, as it does not document events as annals might, but rather presents events in a deliberate manner with much fictitious ornamentation. ${ }^{59}$ Eissfeldt argues that the author of the SN could not have known the private details of the conversations between Amnon and Tamar, David and the woman from Tekoa, Absalom and Ahithophel, and Absalom and Hushai. In addition to these 'fantasies,' Eissfeldt remarks that the writer of the SN used a good deal of poetic licence in creating the story. ${ }^{60}$

The research in this thesis supports Eissfeldt's claim that the SN contains historical information combined with literary fantasy. ${ }^{61}$ However, Eissfeldt does not mention irony when he speaks of literary fantasy, but rather focuses on private conversations. Nor does Eissfeldt characterise the SN as satire.

Gunn builds on these ideas by suggesting that the material in the $\mathrm{SN}$ is primarily a work of art and an entertaining story. ${ }^{62}$ Gunn argues that this story is traditional in nature, drawing on motifs found in the OT and in other literature. Gunn's argument that the SN is a work of art and an entertaining story which is serious, ${ }^{63}$ greatly influenced my research. Indeed, Gunn's view was the starting point for the development of my own view that the $\mathrm{SN}$ is a satire.

\footnotetext{
$5^{6} \quad$ Eissfeldt, The Old Testament. An Introduction.

57 Gunn, The Story of King David. Genre and Interpretation.

58 Otto Eissfeldt, The Old Testament. An Introduction (Oxford: Basil Blackwell, 1966), 143.

59 Ibid., 48.

$60 \quad$ Ibid., 141.

61 Eissfeldt, The Old Testament. An Introduction, 143.

62 Gunn, The Story of King David. Genre and Interpretation, 13. Although Gunn does use the term 'Succession Narrative,' it is worth noting that he does not believe that Solomon's ascension is the primary focus of this narrative; indeed, Gunn writes that Solomon is scarcely mentioned in the narrative. Instead Gunn views this as a narrative, where David is the protagonist of the story. 82 .

63 Gunn, The Story of King David. Genre and Interpretation, 13.
} 
However, taking the SN as a work of satire means that I have diverged from Gunn's views. Gunn does recognise episodes of irony within the narrative. ${ }^{64}$ However, Gunn does not argue that David is the principal object of sustained ironic attack in the SN by virtue largely of his moral transgressions. Instead Gunn argues that although David's behaviour raises some ethical questions, the SN does not moralise. ${ }^{65}$ If Gunn is right then the irony in the SN is presumably merely observable irony rather than verbal irony. For observable irony does not necessarily involve authorial intention, let alone a moralising author. Contrary to Gunn's perspective, I interpret the SN from the perspective of verbal irony. Moreover, my findings include the proposition that the pejorative criticisms of David, Amnon, Absalom and Solomon are moral criticisms since they point to their moral failings. Despite this divergence of views, I owe a debt to Gunn's research, and to his long-standing conversation with Van Seters; specifically, to the argument that the $\mathrm{SN}$ is akin to the kind of writing which is found in Njals Sagas.

\subsubsection{Njals Saga}

The suggestion that the SN is a saga in the tradition of Njals Sagas is compatible with my findings. Van Seters' argument that the SN, or what he calls the 'David Saga,' is a fictitious account of history, ${ }^{66}$ which subverts or satirizes an otherwise accepted account of history is in keeping with satire. ${ }^{67}$ However, whereas, Van Seters suggests that the 'David Saga,' parodies an earlier document, my argument is that the SN offers a different perspective much in the same way as a political satirist today might. Parody is certainly an element of the findings of this research, but it is only one element amongst many. In any case, the existence of such an earlier document is contentious.

Van Seters' proposal that the material in $\mathrm{SN}$ is anti-monarchical ${ }^{68}$ is supported by my findings. However, the findings of this research diverge decisively from Van Seters' views with respect to my claim that the genre of the SN is satire. Van Seters does not make this claim. Moreover, the elements of satire are different to the features of Njals Sagas; the latter are not always satirical in nature. I argue that the traditional features of satire, particularly verbal irony, pervade the SN.

\footnotetext{
64 Ibid., 45, 91, 93, 95, 97, 98, 100.

65 Ibid., 110.

66 Van Seters, The Biblical Saga of King David, 43.

67 Ibid., 354-355.

68 Ibid., $35^{8}$.
} 


\subsection{Conclusion}

It has been argued that there is a pervasive sense of verbal irony the $\mathrm{SN}$ and, therefore, an object of sustained ironic attack, primarily King David. Moreover, it has been argued that the SN contains multiple instances of the other elements of satire. These findings in themselves are sufficient to demonstrate that the $\mathrm{SN}$ is a satire. This argument has been strengthened by way of a comparison between the findings of my research (specifically, that the $\mathrm{SN}$ is a satire) and the alternative extant proposals in respect of the genre of the $\mathrm{SN}$.

In relation to the early history of interpretation of the $\mathrm{SN}$, the findings of this research contrast with Wellhausen's interpretation of the stories in the SN as history writing which is pro-David. ${ }^{69}$ The caustic expression which is directed at David would seem to counter this argument. Luther's suggestion that this same writing is novelistic in style, and is concerned to show the complexities of David's character, ${ }^{70}$ is also challenged by the interpretation of $\mathrm{SN}$ as satire. In particular, it has been argued that David is not portrayed as being as faithful as Luther suggests, and that David's despotism is emphasized more than Luther allows for. Caspari, on the other hand, argues that the narrative is too serious to be called a novella and that it is more akin to historiography. ${ }^{71} \mathrm{An}$ interpretation of satire is compatible with the degree of seriousness that Caspari was grasping for, and is indeed more serious than a historiography since satires call for reform. Similar comparisons are made with the work of Gressmann and Schulz.

Pfeiffer's argument that the $\mathrm{SN}$ is a national epic ${ }^{72}$ is refuted by the findings of this research which show that David is not portrayed as a heroic king. As far as the genre of propaganda is concerned, the interpretation of the $\mathrm{SN}$ as satire compliments the thesis that the $\mathrm{SN}$ is anti-David, Absalom, and Amnon propaganda. Yet, although satire is similar to propaganda in some respects, it is also different. Specifically, satire seeks reform and a considered response from the audience, whereas propaganda does not encourage objectivity. The idea that the SN is pro-David propaganda is, therefore, refuted. It is similarly argued that the $\mathrm{SN}$ is too ambiguous to serve as a pedagogic resource in line with Whybray's argument that the $\mathrm{SN}$ is wisdom literature. ${ }^{73}$

69 Wellhausen, Prolegomena to the History of Ancient Israel, 105.

70 Luther, "The Novella of Judah and Tamar and Other Israelite Novellas," 101-106.

71 Caspari, "The Literary Type and Historical Value of 2 Samuel 15-20," 82-84.

72 Pfeiffer, Introduction to the Old Testament, 357-358.

73 Whybray, The Succession Narrative. A Study of II Sam. 9-2o and I Kings 1 and 2, 56. 
The idea that the SN is theological 'history' writing as has been argued by Von Rad, Brueggemann, McKenzie, and Mann, is compatible with the findings of this research, e.g. that David is criticised for not following the laws, and that the flow of events consists in the outworking of God's punishment of David. However, these theorists offer more benign interpretations than satire. This is evidenced by the findings of Brueggemann and Mann who interpret this narrative as portraying the strength of David's faith. On the other hand, my own interpretation of SN as satire suggests that the author of the SN is heavily critical of David's transgressions, and his lack of faith. My findings support the proposition that the broad genre to which the SN belongs is that of literary art, given the aesthetic quality of the narrative. Most saliently, this research supports Gunn's proposition that the $\mathrm{SN}$ is a serious work of art. ${ }^{74}$ However, my own interpretation involves the common-sense acceptance of an author and, therefore, of authorial intention. Moreover, this author intends to be highly critical of David's moral transgressions. So, my interpretation of the SN differs from that of Gunn. Gunn argues that the SN is not a moral tale. ${ }^{75}$ The findings of my research have the most in common with Van Seters' argument that the material in the $\mathrm{SN}$ is satirical. ${ }^{76}$ However, whereas Van Seters suggests that this material is akin to a njals saga, according to my own interpretation the SN is a satire. I argue that the designation of satire is more precise than that of njals sagas since the latter are not always satirical in nature.

74 Gunn, The Story of King David. Genre and Interpretation, 13.

75 Ibid., 110.

76 Van Seters, The Biblical Saga of King David, 354-355. 